\title{
Chapter 25 \\ Community-Based Tourism as a Strategy for Building Climate Resilience in Bhutan
}

Ngawang Dendup, Kuenzang Tshering, and Jamyang Choda

\section{Key Messages}

- Climate change is affecting the rural households whose primary livelihood is agriculture.

- Community tourism can benefit rural households and provide alternative source of livelihood.

- Households from community that received community tourism program are more likely to have better household wealth (i.e. number of rooms and vehicle ownership).

\subsection{Introduction}

Bhutan is regarded as one of the most exclusive travel destinations with its reputation for authenticity, remoteness, well-protected cultural heritage and its pristine natural environment (Montes, 2019; RGoB, 2012; Rinzin et al., 2007; TCB, 2019; WWF, 2011). Tourism has been one of the highest revenue generators of the country over the past decades (NSB, 2019; TCB, 2020) and has grown consistently over the years. In addition, the tourism industry is one of the highest foreign currency earners for Bhutan (NCoB, 2016) and according to the annual Tourism Monitor Report 2019,

\footnotetext{
N. Dendup ( $\square)$

Waseda University, Tokyo, Japan

e-mail: ngawangdendup@ gmail.com

K. Tshering

Edith Cowan University, Perth, Australia

e-mail: k.tshering@ecu.edu.au

J. Choda

Perth, Australia

e-mail: jamyang@sherubtse.edu.bt
} 
the gross foreign exchange earnings from international and regional tourists was 88.6 million US dollars.

However, Bhutan's tourism sector is strictly regulated and tourists are required to adhere to the 'daily minimum package' set by the government (Dendup \& Tshering, 2018; Montes, 2019; NCoB, 2016; Nyaupane \& Timothy, 2010; RGoB, 2012; Rinzin et al., 2007; TCB, 2019). Tourism is only allowed to operate within a limited sphere of government facilities, designated hoteliers and tour operators including communityled tourism facilities such as 'home stays' and 'farm houses' with tourists required to book the trip via a local tour operator and no back-packing allowed. However, it is not evident if communities or households are benefitting from this. This chapter attempts to assess whether the benefits of tourism are reaching households and communities using the latest census data. The financial data related to the tourism industry is available for international tourists, generally categorized into international and regional, the latter comprising of tourists from India, Bangladesh and Maldives who are exempted from the 'minimum daily package'. However, in this chapter, the benefit accruing from tourism is assumed as cumulative from both local and international tourists.

To maintain its status as an exclusive travel destination and to safeguard its heritage, Bhutan strictly adheres to its tourism policy of 'high value-low impact tourism' based on its sustainable development concept of Gross National Happiness (TCB, 2020), despite potential threats to this model from increasing arrivals of both regional (Brunet et al., 2001; Teoh, 2016) and international tourists (Basnet, 2020; Montes \& Kafley, 2019). Tourism in Bhutan has been founded on the principles of promoting the environment, preserving local cultural heritage and encouraging economically viable activities (Reinfeld, 2003; RGoB, 2012; TCB, 2019). The carrying capacity of the natural environment and cultural landscape has been a determining factor in shaping tourism policy. For example, even locals are prohibited from visiting many culturally significant sites in the higher altitude of Bhutan during certain times of the year, providing a fragile mountain ecosystem with time to regenerate. Such restrictions imposed across Bhutan under both mainstream conservation laws and customary practices have been very effective in reducing the impacts of tourists on local touristic hotspots like Aja Ney, Singye Dzong and many others. The effectiveness of local customary practices has been acknowledged in reducing pressure on rangelands (Moktan et al., 2008; Tshering et al., 2016) and found to be beneficial in maintaining biodiversity, especially the country's rich faunal diversity (WWF, 2011).

On the other hand, community-based tourism in Bhutan is also being promoted to reduce the vulnerability of the community to effects of climate change and economic shocks. In a subsistence farming economy like rural Bhutan, the majority of farmers are dependent on food crops that are dominated by rainfed agriculture. Every year farming communities lose crops to wind storms, wildlife, pest and erratic rainfall (MoAF, 2017), which could worsen with climate change. Recent policy has therefore ensured that every conservation project in Bhutan implements community-based tourism as a way of enhancing community resilience to reduce vulnerability to climate change. Besides tourism, there are other strategies like migration, alternative farming, 
crop diversification and also using mobile-based social networks that can also build resilience in rural communities (see similar experiences documented by Ghosh and Roy (2021, Chap. 26 of this volume, Gunathilaka \& Samarakoon 2021, Chap. 27 of this volume, Shafeeqa \& Abeyrathne 2022, Chap. 9 of this volume and Nazir \& Lohano, 2022, Chap. 28 of this volume).

One of the biggest conservation projects, 'Bhutan for Life', which is under implementation and planned to continue till 2032, has identified numerous key performance indicators on promotion of ecotourism and nature-based business models in all the protected areas (BFLS, 2019). Similar approaches are visible in numerous development initiatives, particularly those being implemented within the protected areas of Bhutan, which cover more than $50 \%$ of the country. For instance, the National Sheep Breeding Farm has been supporting the farmers' group under Phobjikha and Gangtey (one of the study sites) for production of woollen handicrafts and products as a means of creating alternative income generation from the sale of products to tourists visiting the valley (BTFEC, 2019; The World Bank, 2019). Further, the potential of community-based tourism was also reported by Gurung and Seeland (2011) during an assessment on ecotourism impacts on three communities within the protected areas (Jigme Dorji National Park, Jigme Singye Wangchuck National Park, Phrumsingla National Park) of Bhutan, suggesting a potential for expansion of the ecotourism business model in the country.

The Department of Forest and Park Services, the government agency entrusted with conservation of natural biodiversity of the country, has also embraced the concept in order to promote incentive-based conservation initiatives. The Department promotes ecotourism, as a way of generating alternative income for communities in and around the protected area network system who have often had to forgo numerous economic opportunities under the strict conservation regulations (Penjore, 2008).

The significance of the tourism industry for promoting balanced regional development was also emphasized in the current five-year national development plan-12th Five Year Plan (2018-2023) — where a priority programme has been planned as a 'sustainable tourism development flagship programme' (GNHC, 2019). In general, community-based tourism and ecotourism in the context of Bhutan refer to a platform for the local community to generate economic benefits through offering their products to tourists (both national and international) that ranges from local community lifestyles and natural resources to culture. It is being run as a development programme that is expected to enhance social and cultural benefits to the locals as well as the tourist (Donny \& Nor, 2012).

Key tourism products in community-based projects include homestays and farmhouses, traditional hot stone bath, local games like archery and darts, hiking with local guides, and local festivals (e.g. mushroom festival, rhododendron, highland). Some communities in touristic areas also earn income through offering porter and pony services during trekking by international tourists and pilgrimage by local tourists. In certain locations like Khoma village under Bumdeling Wildlife Sanctuary, promotion of the textile industry has been the key income source for the locals. In other areas, community groups have been formed for the management of medicinal plants, black-necked crane conservation, human-wildlife conflict and other issues (BTFEC, 2019; World Bank, 2019). 
The managers of the protected area have been instrumental in developing infrastructures such as trekking routes and camping facilities at hot springs and culturally significant touristic sites with funding support from the central government, while the management has been mostly handed over to the local farmers' or youth groups. For example, since 2018, the guesthouse, campsites, and trekking routes built by Bumdeling Wildlife Sanctuary in and around the local pilgrimage hotspot Aja Ney have been handed over to the local community for management. The local farmers group of 16 households manages the facilities and makes a substantive income from it (BTFEC, 2019; World Bank, 2019).

The majority of community-based tourism initiatives in Bhutan are within the protected areas network, which includes parks, wildlife sanctuaries and the network of biological corridors. Any developmental activities are in accordance with the long-term park management plans, which are always within the framework of the government's planning processes. For the communities of Phobjikha and Gangtey sub-districts, which falls within a biological corridor, the community-based tourism was initiated by a local CSO, the Royal Society for Protection of Nature (RSPN) within the framework of overarching management policies set by the Department of Park and Forests Services, the ultimate authority for protected area management in Bhutan (RGoB, 2012).

\subsection{Study Area: Bhutan Context}

In this study, we consider Gangtey and Phobjikha sub-districts under Wangdiphodrang district, Chhokhor, Tang and Ura sub-districts under Bumthang district and Bumdeling sub-district under Tashiyangtse district as community tourism initiatives (treatment) have been introduced here for some time past and the benefits may not be visible in other areas where the initiatives have been introduced more recently.

The sub-districts that are considered treatment sub-districts are reported in Table 25.1 along with the number of tourist arrivals, district and national park or protected area they fall under.

The main attraction for international tourists in Bumdeling, Phobjika and Gangtey is the presence of the Black-neck crane, a charismatic species with significant spiritual and cultural value for the locals. The marshland of Gangtey and Phobjikha is one of the biggest winter roosting grounds for the migratory bird flying from the Tibetan Autonomous Region of China to Bhutan every winter. The riverine wetlands along the Kholong Chu River under Bumdeling sub-district are another vital winter roosting ground for the crane (RGoB, 2018; RSPN, 2014). These wetlands are also listed as internationally important wetlands and comprise two of the three RAMSAR sites in Bhutan. Other sub-districts like Chhokhor and Tang also receive some cranes in the winter. The engagement of the community, through incentive-based initiatives is vital for meeting conservation and development targets in such critical ecosystems which are vulnerable to climate change. 
Table 25.1 Treatment sub-districts with number of tourist arrivals

\begin{tabular}{l|l|l|l|l}
\hline S. No. & District & Sub-district & $\begin{array}{l}\text { Number of } \\
\text { international } \\
\text { visitors }{ }^{1} \text { in 2019 in } \\
\text { district }\end{array}$ & $\begin{array}{l}\text { Protected area } \\
\text { manager }\end{array}$ \\
\hline 1 & Wangdue Phodrang & $\begin{array}{l}\text { Phobjikha }^{2} \text { and } \\
\text { Gangtey }\end{array}$ & 30,090 & $\begin{array}{l}\text { Biological } \\
\text { corridor-8 }\end{array}$ \\
\hline 3 & Bumthang & $\begin{array}{l}\text { Choekhor, Tang and } \\
\text { Ura }\end{array}$ & 30,580 & $\begin{array}{l}\text { Wangchuck } \\
\text { Centennial National } \\
\text { Park }\end{array}$ \\
\hline 6 & Trashi Yangtse & Bumdeling & $\begin{array}{l}\text { Bumdeling Wildlife } \\
\text { Sanctuary }\end{array}$ \\
\hline
\end{tabular}

\footnotetext{
${ }^{1}$ These figures shows only international visitors in 2019 as per annual Tourism Monitor Report prepared by Tourism Council of Bhutan (TCB, 2020), thus it doesn't provide any information on number of local tourists. In places Phobjikha and Gangtey, income from local tourist can also be significant part of annual income for home-stays by hosting holidaymakers from capital city Thimphu. Some of the home-stays have also been hosting in-house workshops for smaller groups from numerous offices in Thimphu. Similarly, a significant number of local tourist on pilgrimage to Pemaling and holidaymakers to Bumdeling valley are expected to create significant impact on local income generation.

${ }^{2}$ Managed by Royal Society for Protection of Nature (RSPN), registered CSO in Bhutan. The area is also one of the three RAMSAR sites in Bhutan.

${ }^{3}$ Second RAMSAR site in Bhutan.
}

The majority of places that are promoted as tourist destinations in Bhutan fall under protected areas or biological corridors. In these areas, the benefits and restrictions are usually well communicated with the key stakeholders even at the level of individual households in order to gain their support. Participatory community planning is the first step, and the park managers actively engage with the local government. The plan is thoroughly discussed with all the key stakeholders, mainly those households willing to participate in ecotourism. These households are then provided technical and material support in terms of health and hygiene and hospitality management, in most cases, for improving basic washroom facilities to enable them to host tourists. The local community is expected to adhere to the restrictions under the Forest and Nature Conservation Act of Bhutan 1995. For example, in Phobjikha and Gangtey sub-districts, households are allowed to practice agriculture, but face restrictions on using pesticides and inorganic fertilizers. Park managers report that such communityled projects have been very successful in the management of the natural environment especially the fragile high altitude ecosystems which are not only often under extreme threat from climate change but also the least monitored due to remoteness. In some areas like Jigme Dorji National Park, Wangchuck Centennial National Park and Bumdeling Wildlife Sanctuary, the attitude of local communities towards conservation has significantly improved through such community-led projects (BTFEC, 2019; The World Bank, 2019). The promotion of sub-districts within national parks 
or biological corridors as eco-tourist destinations reduces pressure for development of infrastructure like roads and mainstream tourism industry development like hotels.

Key challenges for the management of wetlands of international significance, like Bhutan's RAMSAR sites such as the Phobjikha wetland, include agriculture activities like indiscriminate grazing, reclaiming of wetland areas for agriculture and the heavy use of chemical fertilizers, pesticides and herbicide. Wetlands along the tourist hiking trails were also reported to be under increasing pressure from the increasing number of people and the grazing of horses from the porter services. There were also localized cases of invasive species like water hyacinth taking over the wetland system in a freshwater lake at Samtegang, probably due to increasing sediment flow into the lake and warmer climate due to climate change. In Bumdeling RAMSAR site, the annual flash floods due to erratic monsoon rainfall have washed away huge areas of wetland (RGoB, 2018; Rinzin et al., 2007; RSPN, 2014). The wetlands face imminent threat from climate change, which is the biggest concern for the managers of the protected areas, who often lack appropriate data, knowledge and tools for reducing the vulnerability of the local communities. Anecdotal evidence from the Ecotourism Section under the Nature Conservation Division of Department of Forest and Park Services recommends community-based tourism as one of the most effective tools in promotion of incentive-based conservation in Bhutan and for reducing the economic vulnerability of the local communities to the negative effects of climate change.

\subsection{Identification Strategy}

In this section, we describe the identification strategy that we use to assess the impact of community-based tourism on household wealth. The households from six sub-districts reported in are treatment sub-districts. The community-based tourism in Gangtey and Phobjikha in the western region was started through the initiative of RSPN, while Chhokhor, Tang and Ura in Bumthang in the central region and Bumdeling in the eastern region were supported through numerous environmental conservation projects funded by the government channelled through the management of Wangchuck Centennial National Park, Phrumsingla National Park and Bumdeling Wildlife Sanctuary. These sites were selected to ensure regional representation of the community-based project sites. Further, community tourism initiatives under these six sub-districts have been promoted to improve community resilience to weather and climate shocks (BFLS, 2019; BTFEC, 2019; The World Bank, 2019). The decision to promote these six sub-districts for community tourism was obviously not random and hence, household wealth from above-treated sub-districts cannot be directly compared with households from other sub-districts that did not receive community tourism programmes. The community tourism initiatives were promoted specifically for conservation. The second source of non-randomness arises at the household level. Once the tourism initiative arrives in the community, it is the decision of households to determine the degree of engagement in participating in the community tourism 
activity, and this also drives the household income. In order to circumvent nonrandom assignment of community tourism initiatives in Bhutan, this study adopts propensity score matching. We match households from treated sub-districts with households from control sub-districts that are similar in observed characteristics or that have similar treatment probability, using nearest neighbour matching. Using only those matched households, we estimate the following model

$$
w_{i}=\beta_{0}+\tau \text { Tourism }_{i}+X_{i} \theta+\epsilon_{i}
$$

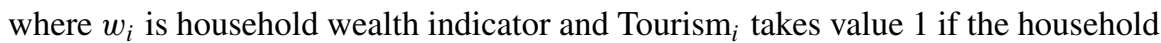
belongs to sub-districts that received community tourism initiatives and zero otherwise. The parameter $\tau$ is the effect of receiving community tourism initiatives and vector $X_{i}$ is a vector of other control variables. We estimate both linear probability model and probit model for Eq. (25.1). Similar identification strategy on matched sample was also implemented by Brucal et al. (2019) and Litzow et al. (2019).

In Eq. (25.1), we only use households that are similar in observed characteristics based on propensity score matching; hence, the unconfoundedness assumption holds. However, propensity score matching does not account for the selection on unobservables or if unobservables in $\epsilon_{i}$ is correlated with community or householdlevel characteristics that also determines the probability of receiving the tourism initiatives from government, $\tau$ may be biased. However, this is of less concern to us, because of the following two reasons. First, Bhutanese society is homogenous unlike other South Asian countries and hence, unobservables should also be similar. Second, vector of controls in Eq. (25.1), includes a host of variables that may have affected the government's decision to implement tourism initiative, and hence, the variables Tourism is exogenous after controlling for observed households and individual characteristics. Therefore, we believe that our identification strategy has substantially mitigated concern over non-random assignment of the government tourism initiatives in particular areas.

\subsection{Data}

This study uses the 2017 Population and Housing Census (PHCB) (NSB, 2018) which was conducted in 2016-2017. It has collected information from entire households in both rural and urban Bhutan. According to the 2017 PHCB, there are about 163,001 households in Bhutan, of which about $63 \%$ are classified as rural households. In this study, we use rural households since our objective is to understand the impact of tourism on rural households. PHCB has collected data at both household and individual level.

Based on our definition of treatment households, about 3033 households or about $3 \%$ of rural households are treated with community tourism initiatives. From the total of 3033 households, we could find match households from the control group for 1033 households. In this study, control group refers to households from those 
sub-districts that did not receive community tourism programmes. This reduction in the number of matched households is partly due to inclusion of many confounding household and individual characteristics for the matching purposes or estimating propensity score. The differences in the mean before matching are significant for almost all of the variables. After matching, the mean differences are significant for only seven variables. Therefore, the vector of controls in Eq. (25.1) includes those significant variables as well as demographic characteristics of household heads.

In this study, we examined the effect of tourism on three important wealth indicators in rural settings: numbers of rooms, modern floor and ownership of vehicles. Based on the matched sample, the average number of rooms is about 4 with 8 as the maximum number of rooms. However, when estimating Eq. (25.1) for the number of rooms, we use binary variable indicating 1 if the number of rooms is more than four and zero otherwise. About $9 \%$ of households have reported as having a modern floor, and about $36 \%$ of households have reported as owning a vehicle which includes a family car or vehicle for commercial purposes.

\subsection{Results and Discussion}

The results of Eq. (25.1) from the linear probability model are reported in Table 25.2, panel A and the results of probit models and average marginal effects from the probit model are reported in Table 25.2, panel B. Both linear probability models and probit models are estimated using frequency of match as weights in the regression. In linear probability models, the standard errors are clustered at sub-district level. The standard errors for marginal effects are calculated using Delta method. The results from linear probability model and probit models are comparable both in terms of the effect size and significance level.

The results from the linear probability model suggest that households that are exposed to community-based tourism treatment are likely to have 0.5 more rooms compared to control households. Similarly, household size, age and female-headed households are also positively correlated with the number of rooms. On the other hand, households headed by married heads are negatively correlated with the number of rooms, perhaps due to tradeoffs that households face between children expenditure and upgrading the house. Other assets such as ownership of television, livestock and washing machines, are also positively correlated with the number of rooms. Similarly, treated households are about $6 \%$ more likely to own a vehicle compared to control households. Household size, marital status, age and level of education are positively correlated with vehicle ownership while female-headed households are negatively correlated with vehicle ownership, perhaps due differences in household needs prioritizations. Similarly, ownership of television, mobile internet and washing machines are also positively correlated with the ownership of vehicles.

The average marginal effect from the probit model, reported in Table 25.2, panel $\mathrm{B}$ also shows similar results. The results show that households from communities that have received the community tourism initiative are about $10 \%$ more likely to 
Table 25.2 Effect of tourism on household wealth

\begin{tabular}{|c|c|c|c|}
\hline & $(1)$ & $(2)$ & (4) \\
\hline Variables & Room $(0 / 1)$ & Modern floor $(0 / 1)$ & Vehicle $(0 / 1)$ \\
\hline \multicolumn{4}{|c|}{ Panel A: linear probability model } \\
\hline \multirow[t]{2}{*}{ Tourism } & $0.469 * * *$ & 0.008 & $0.055 * * *$ \\
\hline & $(0.131)$ & $(0.025)$ & $(0.017)$ \\
\hline Controls & Yes & Yes & Yes \\
\hline Obs & 2068 & 2070 & 2070 \\
\hline \multicolumn{4}{|c|}{ Panel B: probit model } \\
\hline \multirow[t]{2}{*}{ Tourism } & $0.0348 * * *$ & 0.077 & $0.191 * * *$ \\
\hline & $(0.106)$ & $(0.157)$ & $(0.064)$ \\
\hline \multirow[t]{2}{*}{ APE } & $0.096 * * *$ & 0.012 & $0.053 * * *$ \\
\hline & $(0.030)$ & $(0.025)$ & $(0.017)$ \\
\hline Controls & Yes & Yes & Yes \\
\hline Obs & 2068 & 2070 & 2070 \\
\hline
\end{tabular}

Note The binary variable room is defined as 1 if household has more than four rooms, and zero otherwise. Standard errors reported in parentheses for the linear probability model and probit model are clustered at sub-district level. APE stands for average partial effect (or average marginal effect) and standard error for APE is estimated using Delta method

$* * *, * *, *$ indicate significant at 1,5 and $10 \%$ significance level. Control variables include household head's demographics, education, ownership of assets, distance from road, and access to information

have more than four rooms and about 5\% more likely to own a vehicle. The results are highly significant and comparable with the results from the linear probability model. However, for outcome variable modern floor, the results are not significant both in linear probability model and probit model. One of the possible reasons is that there is very limited variation in the outcome variables.

The overall results suggest that there are moderate benefits of community tourism initiatives on rural households. The community tourism initiatives are highly regarded as a successful initiative in Bhutan, and it may be because such initiatives are able to benefit the households directly and hence receive full support from participating communities. Since the majority of these tourism initiatives in Bhutan are linked with conservation of critical ecosystems to combat the adverse effect of climate change, the results suggest that it may help communities in becoming more climate-resilient. The upgrading of houses could enhance earnings from homestay programmes, and these earnings may be invested for income-generating activities such as in the transportation sector through procurement of vehicles. This may also reduce household's dependence on agriculture output, which often is vulnerable to effects of climate change such as erratic rainfall patterns, windstorms, flash floods, emergence of new pests and many others. 


\subsection{Conclusion}

In this chapter, we examined how community tourism initiatives in rural Bhutan enabled households to cope with the effect of changing climate, which is often more exacerbated in fragile mountain ecosystems. Using the household census in Bhutan, we used propensity score matching to examine the effect of community tourism on locally important household wealth indicators. Our results showed that households from the community that received the community tourism initiatives are about 5\% more likely to have more rooms and are also about 5\% more likely to own a vehicle or car. This improvement in wealth indicators may indicate a reduction in the household's dependence on agriculture and hence, this may be an indication that community tourism initiatives in Bhutan may be contributing towards building household resilience to climate change by diversifying income sources away from climate-threatened agriculture.

However, the external validity of these results may depend on how the tourism initiatives are promoted, necessary support from government and overall tourism policy. Community tourism in Bhutan is promoted with caution and policy impacts such as benefits and restrictions are well communicated with the households during the planning period. In some instances, the government has promoted such initiatives through local non-governmental organizations. However, this chapter contributes towards the larger debate of who benefits the most from tourism and also how the tourism sector can also contribute towards building climate resilience in rainfed agricultural rural communities like Bhutan.

Our results also indicate that the benefits from tourism are not limited to revenue generation for the country, but also one of the ways to tackle the current climate change issues. Promoting tourism in rural villages can help poor households not just in terms of enhancing household income but also provide alternative livelihood options in the poor villages. Further, through such community tourism initiatives, the households' reliance on the natural environment such as forest cover and water bodies may also reduce thus providing the space for the natural environment to regenerate.

\section{References}

Basnet, T. R. (2020). Tourism and cultural heritage in Bhutan. Bhutan Law Network/JSW Law Research Paper Series (20-04).

BFLS. (2019). Bhutan for life prospectus. Thimphu.

Brucal, A., Javorcik, B., \& Love, I. (2019). Good for the environment, good for business: Foreign acquisitions and energy intensity. Journal of International Economics, 121, 103247.

Brunet, S., Bauer, J., De Lacy, T., \& Tshering, K. (2001). Tourism development in Bhutan: Tensions between tradition and modernity. Journal of Sustainable Tourism, 9(3), 243-263. https://doi.org/ 10.1080/09669580108667401

BTFEC. (2019). Project impact assessment: Sustainable financing for biodiversity conservation and natural resource management. Thimphu. 
Dendup, N., \& Tshering, K. (2018). Demand for piped drinking water and a formal sewer system in Bhutan. Environmental Economics and Policy Studies, 20(3), 681-703. https://doi.org/10.1007/ s10018-018-0211-3

Donny, S., \& Nor, N. (2012). Community-based tourism (CBT): Local community perceptions toward social and cultural impacts. In 1st Tourism and Hospitality International Conference.

Ghosh, S., \& Roy, S. (2021). Climate change ecological stress and livelihood choices in Indian Sundarban. In A. K. E. Haque, P. Mukhopadhyay, M. Nepal, \& M. R. Shammin (Eds.), Climate change and community resilience: Insights from South Asia (pp. 399-413). Springer Nature.

GNHC. (2019). Twelfth five year plan document (2018-2023) (Vol. I). Thimphu.

Gunathilaka, R. P. D., \& Samarakoon, P. S. M. K. J. (2021). Adaptation by vegetable farmers to climate change in Sri Lanka. In A. K. E. Haque, P. Mukhopadhyay, M. Nepal, \& M. R. Shammin (Eds.), Climate change and community resilience: Insights from South Asia (pp. 415429). Springer Nature.

Gurung, D. B., \& Seeland, K. (2011). Ecotourism benefits and livelihood improvement for sustainable development in the nature conservation areas of Bhutan. Sustainable Development, 19(5), 348-358. https://doi.org/10.1002/sd.443

Litzow, E. L., Pattanayak, S. K., \& Thinley, T. (2019). Returns to rural electrification: Evidence from Bhutan. World Development, 121, 75-96.

MoAF. (2017). Agriculture statistics 2017. Thimphu.

Moktan, M. R., Norbu, L., Nirola, H., Dukpa, K., Rai, T. B., \& Dorji, R. (2008). Ecological and social aspects of transhumant herding in Bhutan. Mountain Research and Development, 28(1), $41-48$

Montes, J. (2019). Environmental governance in Bhutan ecotourism. Wagenigen University.

Montes, J., \& Kafley, B. (2019). Ecotourism discourses in Bhutan: Contested perceptions and values. Tourism Geographies, 1-24. https://doi.org/10.1080/14616688.2019.1618905

Nazir, A., \& Lohano, H.D. (2022). Resilience through Crop diversification in Pakistan. In A. K. E. Haque, P. Mukhopadhyay, M. Nepal, \& M. R. Shammin (Eds.), Climate change and community resilience: Insights from South Asia (pp. 431-442). Springer Nature.

NCoB. (2016). Review report on tourism policy and strategies. Thimphu.

NSB. (2018). 2017 Population and housing census of Bhutan. Thimphu. ISBN 978-99936-28-50-7

NSB. (2019). Statistical yearbook of Bhutan 2019. Thimphu.

Nyaupane, G. P., \& Timothy, D. J. (2010). Power, regionalism and tourism policy in Bhutan. Annals of Tourism Research, 37(4), 969-988. https://doi.org/10.1016/j.annals.2010.03.006

Penjore, D. (2008). Is national environment conservation success a rural failure? The other side of Bhutan's conservation story.

Reinfeld, M. A. (2003). Tourism and the politics of cultural preservation: A case study of Bhutan. Journal of Public and International Affairs Princeton, 14, 125-143.

RGoB. (2012). Ecotourism development in the protected areas network of Bhutan: Guidelines for planning and management. Thimphu.

RGoB. (2018). Ramsar COP13 national report. Thimphu.

Rinzin, C., Vermeulen, W. J. V., \& Glasbergen, P. (2007). Ecotourism as a mechanism for sustainable development: The case of Bhutan. Environmental Sciences, 4(2), 109-125. https://doi.org/10. 1080/15693430701365420

RSPN. (2014). Study of climate change impact on Wetland ecosystem Phobjikha, West Central Bhutan. Thimphu.

Shafeeqa, F., \& Abeyrathne, R. M. (2022). Climate adaptation by Farmers in three communities in the Maldives. In: A. K. E. Haque, P. Mukhopadhyay, M. Nepal, \& M. R. Shammin (Eds.), Climate change and community resilience: Insights from South Asia (pp. 129-141). Springer Nature.

TCB. (2019). Tourism policy of Kingdom of Bhutan. Thimphu.

TCB. (2020). Bhutan tourism monitor report. Thimphu.

Teoh, S. (2016)."We have become too ambitious, too greedy": Bhutan's gross national happiness (GNH) tourism model. 
The World Bank. (2019). Implementation completion report (ICR) review of project P127490_ Bhutan. Report Number: ICRR0021742.

Tshering, K., Ning, W., Phuntsho, K., Chhetri, N., Bida, N., \& Dema, K. (2016). The fate of traditional rangeland management practices under Bhutan's changing policies and socioeconomic conditions. Bhutan Journal of Research and Development, 53-66.

WWF. (2011). The high ground: Sacred natural sites, bio-cultural diversity and climate change in the Eastern Himalayas. ISBN 978-2-940443-28-4.

Open Access This chapter is licensed under the terms of the Creative Commons AttributionNonCommercial-NoDerivatives 4.0 International License (http://creativecommons.org/licenses/bync-nd/4.0/), which permits any noncommercial use, sharing, distribution and reproduction in any medium or format, as long as you give appropriate credit to the original author(s) and the source, provide a link to the Creative Commons licence and indicate if you modified the licensed material. You do not have permission under this licence to share adapted material derived from this chapter or parts of it.

The images or other third party material in this chapter are included in the chapter's Creative Commons licence, unless indicated otherwise in a credit line to the material. If material is not included in the chapter's Creative Commons licence and your intended use is not permitted by statutory regulation or exceeds the permitted use, you will need to obtain permission directly from the copyright holder.

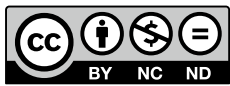

